\title{
NOTES ON THE NESTING HABITS OF SOME OF THE LESS COMMON NEW ENGLAND BUMBLE- BEES. 1
}

\author{
By O. E. Plath, \\ Department of Biology, Boston University.
}

In the fall of 1922, I published a short paper (1922b) on the nesting habits of several of our North American bumblebees. The data recorded were obtained from the study of about 50 nests, most of which were taken in the vicinity of Boston during the summers of 1921 and 1922. Since that time, this number has been increased to over 250 nests, of which more than 200 were examined. Several of these nests belonged to some of our less common New England species, about whose nesting habits-in most cases-comparatively little is known. Among the data presented in the following pages I have included some observations which Dr. Joseph Bequaert and Professor O. A. Stevens were kind enough to communicate to me. Unless otherwise stated, the nests referred to in this paper were taken within the city limits of Boston, either on, or near the grounds of the Arnold Arboretum, or the Bussey Institution.

\section{Terrestris Grour.}

\section{Bremus terricola Kirby.}

Practically nothing was known concerning the nesting habits of this species before the appearance of my first paper (1922 b) which contained data concerning two nests, one taken in the Arnold Arboretum, and the other at Washington, Me. Since then I have been so fortunate as to discover 16 additional nests of this species. One of these was found near the skeleton of a dead rat in a nest which had been built-possibly by this same rat-among some old straw in a box left in the basement of an abandoned greenhouse. The other fifteen were subterranean, and of these, eleven were dug up. These were situated from 6 to

${ }^{1}$ Contributions from the Entomological Laboratory of the Bussey Institution, Harvard University, No. 280. 
18 inches below the surface of the ground, and had entrance tunnels ranging from about 6 inches to $3 \mathrm{ft}$. in length. Most of the colonies did not average over 50 individuals; four, however were considerably larger; one, taken on July 12, 1923, consisting of the old queen, about 50 young queens, and over 150 workers, besides a large number of cocoons. Interspersed with the latter were about a dozen pollen cylinders, similar to those frequently found in the nests of Bremus affinis. These cylinders contained more than a quarter of a pound of pollen.

In an earlier paper (1922a) attention was called to the fact that Psithyrus laboriosus is parasitic on Bremus vagans, while Psithyrus ashtoni is a parasite of Bremus affinis. In a letter, dated March 24, 1923, Professor O. A. Stevens, of N orth Dakota Agricultural College, makes the following comment on the above statement: "I have supposed that Ps. laboriosus must be parasitic on $B$.vagans here. Both species seem especially characteristic of the wooded area along the river. Ps. ashtoni is even more common, but $B$. affinis is rare, so some other host must be sought. I suspect $B$. terricola, but have no direct evidence as yet." As in the case of Dr. Frison's prediction in regard to the host of Psithyrus laboriosus (cf. 1922a, p. 29), I am pleased to be able to confirm Professor Stevens' surmise. On August 8, 1924, I took a nest of Bremus terricola which contained 3 workers, 3 young females of Psithyrus ashtoni, and several males and females of the latter species which had died in their cocoons before hatching. This is the only one of the fourteen nests of Bremus terricola in which young of Psithyrus ashtoni were reared, while 11 of the 36 Bremus affinis nests which have been examined were parasitized by this Psithyrus.

In the summer of 1922, I took two nests of Bremus affinis, one of which contained (1) the old queen, 1 young queen, and 43 workers of Bremus affinis; (2) 12 workers of Bremus affinis var. nova-anglia; and (3) 1 worker of Bremus terricola. The other contained (1) 23 workers of Bremus affinis; (2) 9 workers of Bremus affinis var. novoe-anglice; and (3) 1 worker of Bremus terricola. The heterogeneous nature of these two colonies led me to surmise that Bremus affinis var. novce-anglice might be a hybrid between Bremus affinis and Bremus terricola, these two spe- 
cies being closely related. Since then, however, four more mixed colonies of these two species have been taken, two of which contained a much greater proportion of terricola workers than the two nests found in 1922. The first of these four mixed colonies was taken July 3, 1923. It consisted of the old queen and 6 workers of Bremus affinis, and 1 worker of Bremus terricola. The second was taken on August 9, of the same year, and contained the old queen and about 75 workers of Bremus affinis, and 1 worker of Bremus terricola. The remaining two were both discovered in 1926, one being taken July 5, and the other July 8. The first of these consisted of (1) the old queen and 29 workers of Bremus affinis, (2) 7 workers of Bremus terricola, and (3) a female of Psithyrus ashtoni and a considerable quantity of Psithyrus brood in various stages of development. The other consisted of 15 workers of Bremus affinis, 3 of Bremus terricola, and some brood of Psithyrus ashtoni which hatched later. No additional workers of Bremus terricola hatched from any of these six nests, the first four producing only young of Bremus affinis and, the last two nothing but Psithyrus ashtoni.

As was suggested recently in a joint paper with Dr. Bequaert (1925), the difference in coloration between the typical form of Bremus affinis and its variety nova-anglice is probably due to environment rather than hybridism. The presence of the workers of Bremus terricola in 6 of the 36 affinis nests is easily explained by "natural requeening," a subject which I discussed in a recent paper (1924), the only difference being that in this case, as with Bremus lucorum and Bremus terrestris in Europe (cf. Sladen 1912), requeening is accomplished by a closely related species.

To these data may be added some observations of Professor O. A. Stevens, who informs me that he found a populous nest of Bremus terricola under the floor of a shed, the bees entering by a hole in the roof.

\section{Pratorum Group.}

\section{Bremus perplexus Cresson.}

What is known about the nesting habits of Bremus perplexus we owe to Franklin (1912-13) who took two nests in Vermont, early in August. Both were situated in the walls of houses, and 
were made of wool, one containing 5 queens, 1 male, and 9 workers, and the other 8 queens and 33 workers. I was fortunate enough to discover two nests of this rather rare New England species during the summer of 1925 . One of these was taken on July 3 , under a large root near the base of a tree, the nest being about a foot below the surface of the ground, with a tunnel $2 \mathrm{ft}$. long. In it were found 22 workers, 1 male, and some brood, from which additional males hatched later. The second nest was taken on July 23. It was situated 6 inches below the surface, and, like the first, had a tunnel about $2 \mathrm{ft}$. long. It contained 9 young queens, two of which had recently died, 1 dead male and 357 empty cocoons, showing that this must have been a prosperous colony earlier in the year.

II. Bremus ternarius Say.

Very little is known concerning the nesting habits of this species. In 1863 Putnam (1864) took a nest at Bridport, Vt., which was situated either under an old stump or under the clapboards of a house.

Early in September, 1923, Professor C. T. Brues called my attention to the fact that a nest of Bremus ternarius had been discovered on his summer estate near Petersham, Mass. Through the kindness of Professor and Mrs. Brues it was possible for me - after much digging - to secure the nest of this handsome but vicious species on September 15 . The nest was situated among some trees near a red clover field, and was about $2 \mathrm{ft}$. below the surface of the ground, with a tunnel $6 \mathrm{ft}$. long. This colony consisted of 23 young queens, 16 males, over 100 workers, and a large quantity of brood, with more than 75 young queens still in their cocoons. The colony was transferred to the Bussey grounds where it prospered for over a month. Probably as a result of this transfer, Bremus ternarius, which is rarely found in the vicinity of Boston, was fairly common in the Arnold Arboretum in 1924 and 1925 from early April to October.

\section{Fraternus Group.}

\section{Bremus separatus Cresson.}

The only thing known concerning the nesting habits of this species is Putnam's (1864) statement that Bremus separatus 
builds its nests "under old stumps and in other situations similar to those in which the nests of B. fervidus are found."

I discovered two nests of this species on the surface of a grassy bank on Moss Hill, adjoining the Arnold Arboretum. One of these was found on July 26, 1923, after having been destroyed, probably by a skunk. Among the scattered debris were found three living workers, and the dead bodies of the old queen, two young queens and a fourth worker. The marauder had also left behind over 90 empty cocoons, to which were attached two egg cells, containing 2 and 5 eggs respectively.

The second nest was taken on June 23, 1924. It contained the queen, ten cocoons, a considerable number of larvæ and eggs, and two honey-pots with a common wall (cf. fig. 1). Two

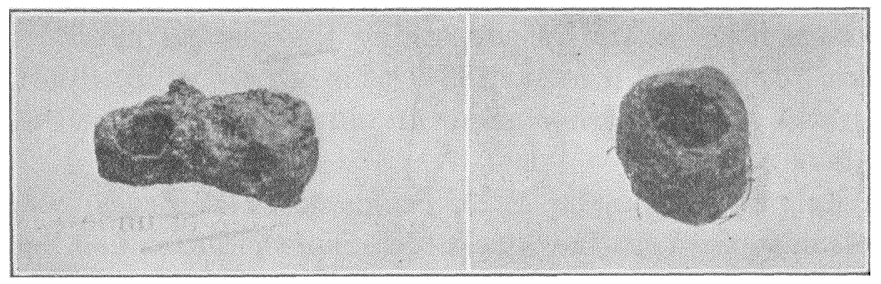

Fig. 1. Double honey-pot of Bremus separatus Cresson.

Fig. 2. Single honey-pot of Bremus impatiens Cresson.

other peculiarities of the double honey pot found in this nest were, (1) that its walls were about twice as thick as those of the single pot (cf. fig. 2) usually found in incipient nests of Bremus impatiens and Bremus vagans; and (2) that it was completely closed at the time the nest was taken, whereas the other two species mentioned apparently never close their honey-pot. ${ }^{2}$ The nest was transferred to one of the windows of the Bussey Dormitory, where other observations were made on this rare species during the remainder of the summer.

Dr. Joseph Bequaert has been kind enough to furnish me with data concerning a nest of this species which he took on July 12, 1918, at Orient, Long Island. The nest was situated in

'Since writing the above, I have discovered the following note by the late F. W. L. Sladen (cf. Root, 1923, p. 172): "The queen's honey-pot in a nest of $B$. fervidus examined at Ottawa, Canada in 1915, was found to be completely closed, possibly a protection of nature, preventing ants, etc., from discovering the honey when the queen is absent from the nest." 
a $\log$ on the seashore and, in addition to the comb, contained the old queen and about a dozen workers.

\section{Dumoucheli Group.}

\section{Bremus americanorum Fabricius. ${ }^{3}$}

Bremus americanorum is one of the most common bumblebees in the central and southern plains of the Middle West, and hence we probably know more about its nesting habits than those of any other of our North American species, chiefly through the work of Franklin (1912-13), Howard (1918), Frison (1916, 1917, 1918, 1921), and Rau (1922, 1924). However, since Bremus americanorum is rare, if not completely absent, in a large part of New England, it seems desirable to record the taking of a nest of this species in the Arnold Arboretum on July 30, 1923.

The nest was discovered in an open field and was about 6 inches below the surface of the ground with a tunnel more than a foot long. In it were found, the old queen, 37 workers, and a considerable quantity of brood. The queen of this colony had only one antenna, but this apparently did not interfere greatly with her duties, since she was seen to oviposit on several occasions during the month of August.

According to Frison (1917, 1918), Ranslow (cf. Howard, 1918), and Rau (1924), Bremus americanorum is rather vicious, a fact which was painfully impressed upon several of my friends shortly after the colony was transferred to the grounds of the Bussey Institution. In fact it was necessary to remove it to another place, since the workers attacked anyone venturing within twenty-five feet of the nest.

\section{Literature Cited.}

Bequaert, J. and Plath, O. E. 1925. Description of a New Psithyrus, with an account of Psithyrus laboriosus, and Notes on Bumblebees. Bull. Mus. Comp. Zool. Harvard. Univ., Vol. 67, pp. 265-288, 2 figs.

${ }^{3}$ Dr. Joseph Bequaert and the writer have recently studied De Geer's description and figure of Bremus pennsylvanicus, and, like Frison (23), have come to the conclusion that it is better to use the name americanorum until the type specimen of De Geer is located. 
Franklin, H. J. 1912-13. The Bombidæ of the New World. Trans. American Ent. Soc., Vol. 38, pp. 177-486, Vol. 38, pp. 73-200, pls. 1-22.

Frison, T. H. 1916. Note on the Habits of Psithyrus variabilis Cress. Bull. Brooklyn Ent. Soc., Vol. 11, pp. 46-47.

1917. Notes on .Bombidæ, and on the Life History of Bombus auricomus Robt. Annals Ent. Soc. America, Vol. 10, pp. 277-286, pls. 23, 24.

1918. Additional Notes on the Life History of Bombus auricomus Robt. Annals Ent. Soc. America, Vol. 11, pp. 43-48, pl. 3.

1921. Psithyrus laboriosus Fabr. in the Nests of Bumblebees (Hym.). Canadian Ent., Vol. 53, pp. 100-101.

1923. Systematic and Biological notes on Bumblebees (Bremidæ; Hymenoptera). Trans. American Ent. Soc., vol. 48, pp. 307-326.

Howard, L. O. 1918. An Unusual Bumblebees' Nest (Hym.). Ent. News, Vol. 29, pp. 114-115.

Plath, O. E. 1922a. Notes on Psithyrus, With Records of Two New American Hosts. Biol. Bull., Vol. 43, pp. 23-44, pl. 1. 1922b. Notes on the Nesting Habits of Several North American Bumblebees. Psyche, Vol. 29, pp. 189-202. 1924. Miscellaneous Biological Observations on Bumblebees. Biol. Bull., Vol. 47, pp. 65-78, 2 figs.

Putnam, F. W. 1864. Notes on the Habits of Some Species of Humble Bees. Proc. Essex Inst., Salem, Mass., Vol. 4, pp. 98-105.

Rau, P. 1922. Ecological and Behavior Notes on Missouri Insects. Trans. Acad. Science St. Louis. Vol. 24, pp. 1-71, pls. 5-8.

1924. Notes on Captive Colonies and Homing of Bombus pennsylvanicus De Geer. Annals Ent. Soc. America, Vol. 17, pp. 368-381, pl. 39.

Root, A. I. and E. R. 1923. The A B C and X Y Z of Bee Culture, pp. 171-177. The A. I. Root Company, Medina, Ohio.

Sladen, F. W. L. 1912. The Humble-bee, Its Life-History and How to Domesticate it. Macmillan \& Co., London. 

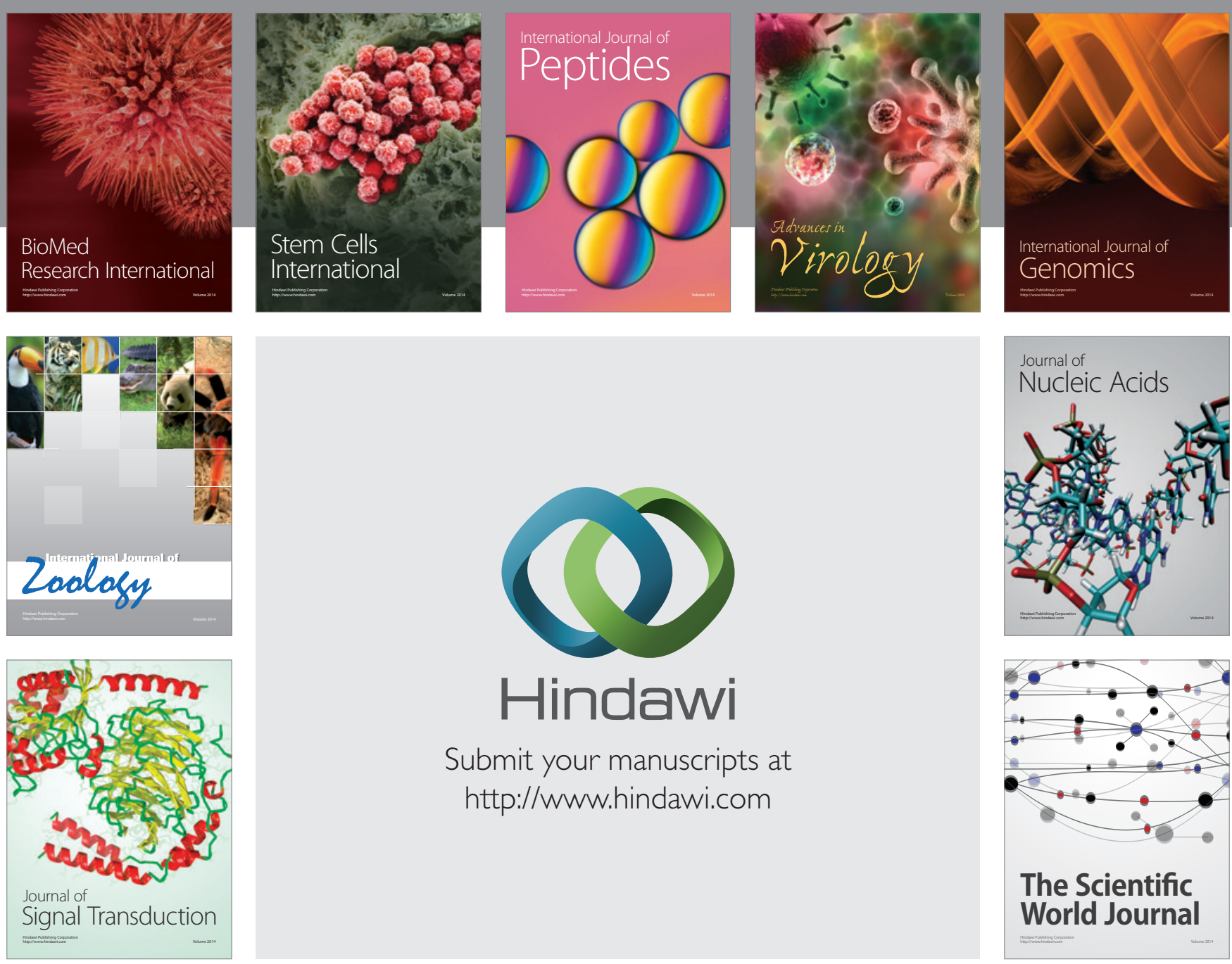

Submit your manuscripts at

http://www.hindawi.com
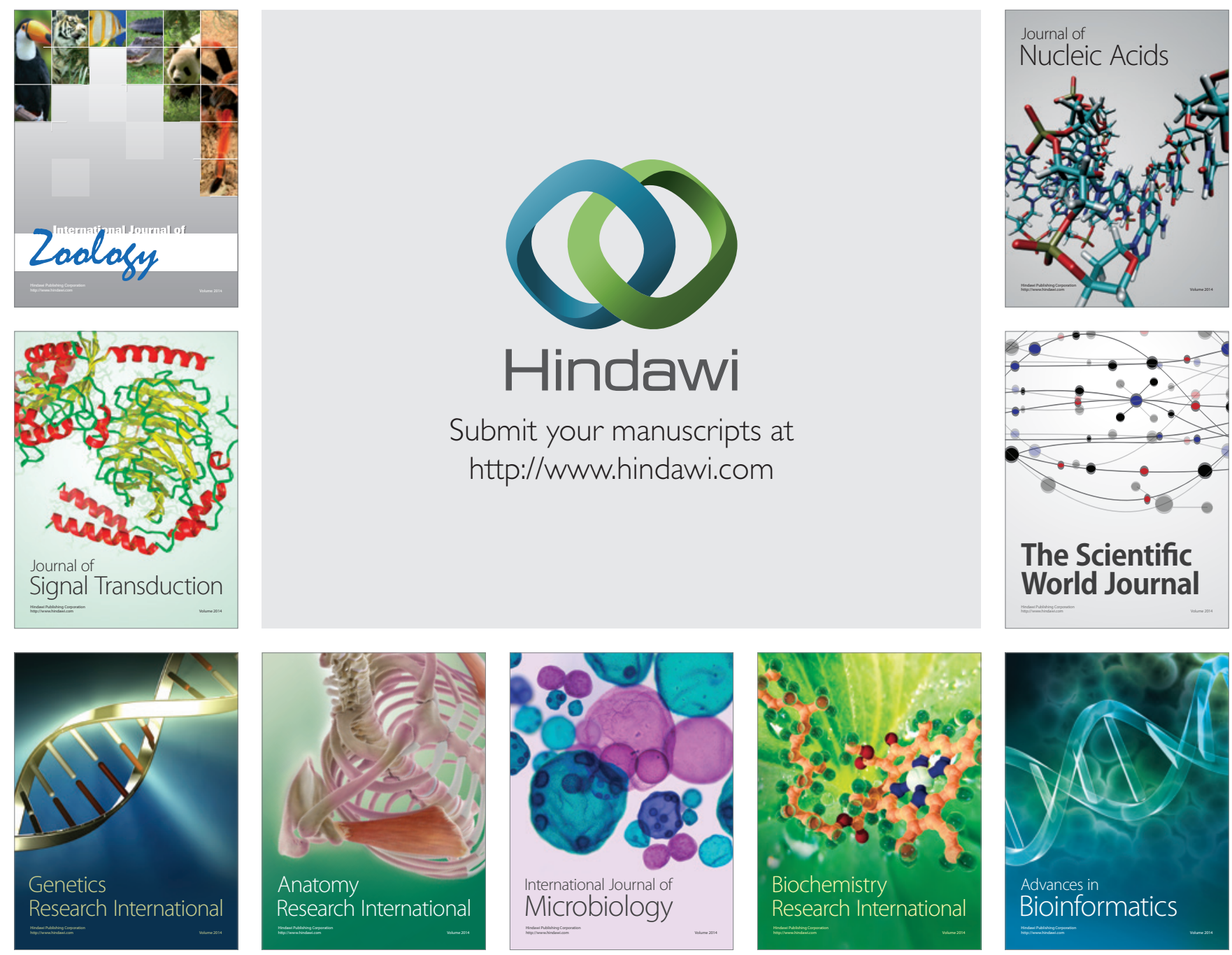

The Scientific World Journal
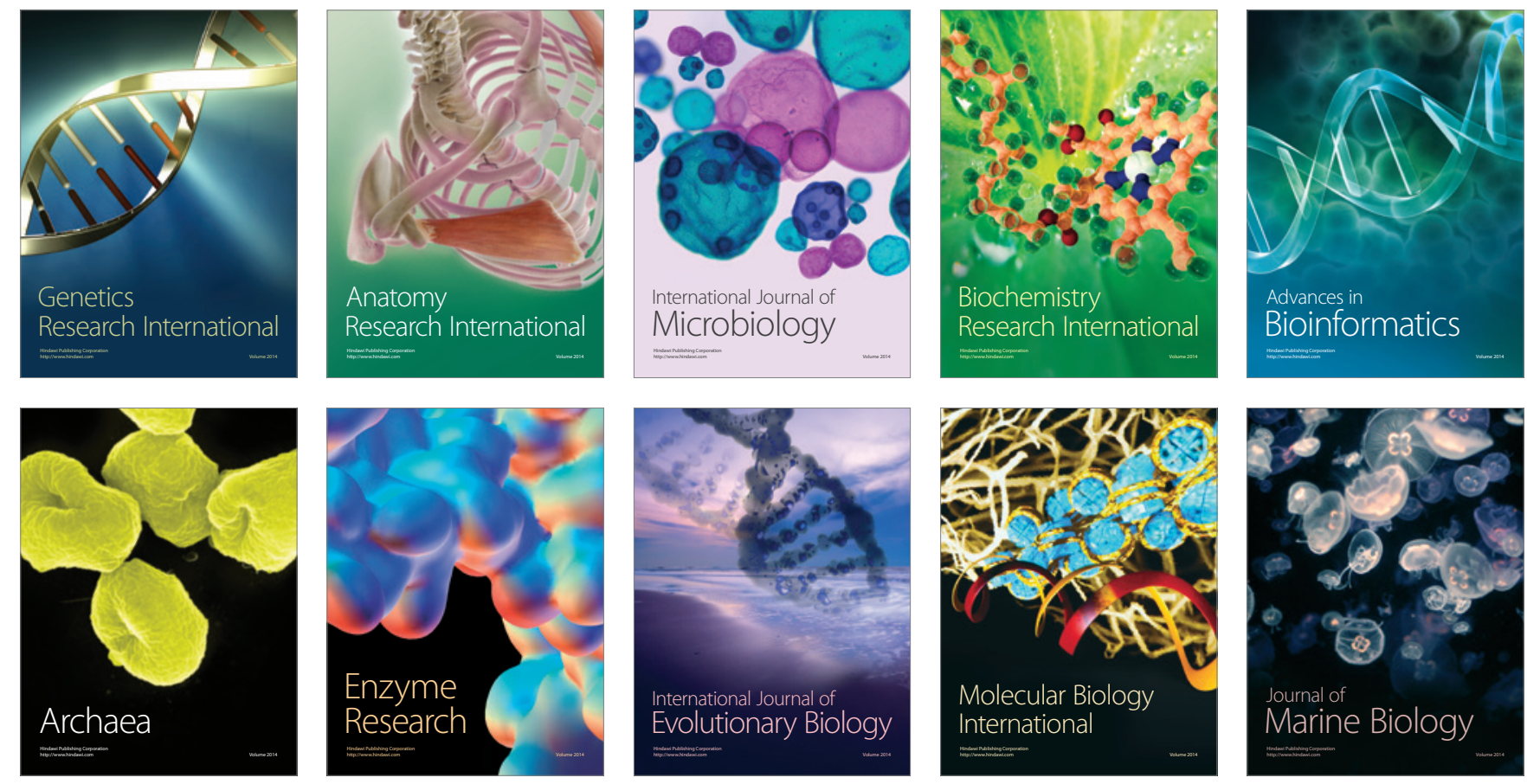